Article

\title{
Visualizing the Forest in a Boreal Forest Landscape-The Perspective of Swedish Municipal Comprehensive Planning
}

\author{
Camilla Thellbro ${ }^{1, *}$, Olof Stjernström ${ }^{2}$, Per Sandström ${ }^{1}$ and Gun Lidestav ${ }^{1}$ \\ 1 Department of Forest Resource Management, Swedish University of Agricultural Sciences (SLU), \\ Skogsmarksgränd, 90183 Umeå, Sweden; per.sandstrom@slu.se (P.S.); gun.lidestav@slu.se (G.L.) \\ 2 Department of Geography and Economic History, Umeå University, 90187 Umeå, Sweden; \\ olof.stjernstrom@umu.se \\ * Correspondence: camilla.thellbro@slu.se; Tel.: +46-70-211-70-02
}

Academic Editor: Timothy A. Martin

Received: 21 March 2017; Accepted: 27 May 2017; Published: 31 May 2017

\begin{abstract}
At the international policy level, there is a clear link between access to information about forests and the work towards sustainable land use. However, involving forests in planning for sustainable development (SuD) at the Swedish local level, by means of municipal comprehensive planning $(\mathrm{MCP})$, is complicated by sector structure and legislation. Currently, there is a gap or hole in the MCP process when it comes to use and access to knowledge about forest conditions and forest land use. This hole limits the possibilities to formulate well-informed municipal visions and goals for sustainable forest land use as well as for overall SuD. Here we introduce an approach for compilation and presentation of geographic information to increase the preconditions for integrating forest information into Swedish MCP. We produce information about forest ownership patterns and forest conditions in terms of age and significant ecological and social values in forests for a case study municipality. We conclude that it is possible to effectively compile geographic and forest-related information to fill the hole in the municipal land use map. Through our approach, MCP could be strengthened as a tool for overall land use planning and hence as a base in SuD planning.
\end{abstract}

Keywords: sustainable development; municipal comprehensive planning; forest data assimilation; forest change analysis; non-industrial private forest owners; forest values

\section{Introduction}

The concept and meaning of local ecological, economic, and social sustainable development originates in the general global definition in Our Common Future, which states that sustainable development $(\mathrm{SuD})$ is an activity that "meets the needs of the present without compromising the ability of future generations to meet their own needs" [1] (p. 8). Agenda 21, the program of action from the United Nations Earth Summit in Rio de Janeiro in 1992, recognizes the role of the local level for global SuD. Agenda 21 states that local authorities play a vital role in finding solutions for global sustainability-related problems because the problems commonly are rooted in local activities and human behaviors. Local authorities represent the level of governance closest to the people and who simultaneously interact with the public as well as with high-level authorities (regional, national, and international) [2-7]. In addition to the local SuD perspective, Agenda 21 identifies local-based spatial planning as important for SuD work [1,2]. Although the role of spatial planning has been questioned over the years cf. [8,9], it is now recognized as an important political tool for long-term sustainability $[10,11]$. Typically, in Europe, regional spatial planning is emphasized [12-15] as well as spatial planning led by the public sector [16]. However, to secure relevance in the planning, 
local and practical examples are generally considered important cf. [17], and in countries with local self-governance such as Sweden, Norway, and Finland, local spatial planning led by the public sector is also possible to carry out. Thus, we argue that local spatial planning, such as the Swedish municipal comprehensive planning (MCP), can be an effective tool in SuD work if the MCP authorities have access to and can provide information about all types of land use cf. [7,11,18].

In Sweden, municipalities as local authorities have a monopoly on spatial planning, meaning, that they have the responsibility for managing territorial and landscape SuD $[7,19,20]$. The foundation of the spatial planning system in Sweden is an active and democratic MCP process that aims for overall SuD. The MCP process and document(s) have four main purposes cf. [19,21]:

(1) to give an up-to-date description of present and future use of land, water and the developed environment;

(2) to facilitate communication between the local and national levels about national interests;

(3) to be a strategic and democratic plan for future land use and development and for the implementation of central directives; and

(4) to guide all other planning in the municipality.

In many regions, forests have been identified as a key to fulfilling long-term objectives of sustainability in European societies through their vital role for socio-economic viability as well as for ecosystems $[13,22,23]$. Thus, knowledge about actual forest conditions and how they have developed is important. As the development of forest conditions is highly affected by the management performed by its owners within the legal frames and policies set up by the state, the owners and their management objectives need to be recognized. Furthermore, it is well known that different forest owners have different objectives and management strategies [24,25], so forest conditions reflect not only present but also past ownership structures [26]. Forest condition also reflects the role of the forest and its use in the overall development of society. For example, in Sweden, commercial use of forest land for timber production has been a main industry for over 100 years, and thus forestry constitutes a strong sectoral interest $[27,28]$. This has been the case for the $40 \%$ of forest land owned by private or state-controlled companies and the $50 \%$ of land in the hands of non-industrial forest (NIPF) owners [29,30].

From a European perspective, Sweden is sparsely populated, forest-dominated, and a forestry-dependent country [22] and the further north, the more sparsely populated and the more forest per inhabitant. Generally, the mechanization of forestry operations and concentration of forest industry has contributed to population declines in many municipalities in the north [31]. Clearly, these circumstances influence on the overall SuD of a municipality. When it comes to the most rural and boreal municipalities, NIPF enterprises constitute about half of all the local small businesses and thereby influence the socio-economic structures and cultural expressions of the local society $[29,32-36]$. Furthermore, several studies show that local tax revenue as well as the development of the local economy and culture is influenced by whether the forest owner lives in the municipality where the forest property is located (resident owners) or lives outside the municipality (non-resident owners) $[24,29,37,38]$. Regardless of residency, how forest owners use their forest resources indisputably affects large areas of a municipal territory. Given the prevailing rotation management practice, about $1 \%$ of the productive forest land is subjected to final felling every year, while another $3 \%$ is cleaned or thinned [39]. Overall, these activities significantly contribute to the landscape's characteristics.

On forest land, spatial planning is carried out on the estate level guided by the objectives of the owner, often expressed in a forest management plan (FMP), with a forestry sector focus and limited landscape consideration. In Sweden, the FMP is governed and regulated by the Forestry Act [40]. The regulations in the Act parallel regulations in the Environmental Code [41], and the Environmental Code regulates any forest land practices not regulated in the Forestry Act [19,40-42]. However, the provisions in the Environmental Code do not apply to on-going land use and final felling, issues that fall under the authority of the Forestry Act. The Forestry Act prioritizes the forestry practices 
of the owners of forest properties, ignoring or at least de-emphasizing land uses such as reindeer husbandry and recreation. Nevertheless, the government and government agencies can appeal to the Environmental Code to designate forest land as a national interest from some aspect of land use other than forestry. According to adjustments to the Forestry Act in 1993, forest management should be carried out with equally valued targets regarding production and preservation of biodiversity. Yet, the increasing recreational and social demands on forest land have initiated a discussion whether social values should complement these stated targets [43]. Forests that hold (or may develop) high social values are characterized by their proximity to habitation, accessibility, and variation in tree composition that includes a predominance of large and old, so-called vital trees. These forests should maintain their natural and aesthetic qualities and be managed to keep (or further develop) these qualities [44-46]. To ensure these requirements are satisfied, authorities and the public need access to detailed knowledge about where to find these forests and who owns them as well as the tools that will encourage more integrated spatial planning.

In contrast to sectorial planning, MCP should include all the important land use activities and needs that occur within a municipality's territory $[19,41]$. We argue that the municipalities need reliable and continuous data of all kinds about land use to develop effective MCP. Yet, as discussed by Stjernström et al. [43] and Bjärstig et al. [47], MCP provides limited integration of forest land such as agriculture, reindeer husbandry, mining, and wind power development. However, MCP is clearly influenced by the business sectorization of authorities and data (general information, statistics, geographic data, etc.) and by property rights and other legislation [48]. Sectorization makes it difficult to develop a more holistic view of natural resource use in society, the aim of MCP [35,49,50]. In present planning processes, property rights have a strong position relative to the public interest. However, the balancing act between property rights and the public interest is formally handled in the public planning process through the possibility of expropriation if the public interest is endangered or limited [43]. Laws and regulations associated with the environment and spatial planning separate forestry interest from the public planning to protect property rights and forest production [42,43]. Nevertheless, MCP aims for sustainable development, which implies planning for vital natural ecosystems, sustainable land use, social services, and infrastructure. This planning should be done for the benefit of all local inhabitants and businesses, including forest owners and forest enterprises, with consideration to regional and national policies and goals [21,29,35,51]. One argument for incorporating information about forest land use into the $\mathrm{MCP}$ is therefore the prospect of finding a more equal balance among the interests of private land owners, the public, and the state. A concrete example from the Swedish case is the Swedish practice of the Right of Public Access, which is commonly accepted by the public as well as by all forest owners. In many ways, this practice is a prerequisite for various land uses such as organized as well as privately-conducted recreational activities and tourism (which should be strategically planned for in MCP), but to some extent it limits property rights [19,52]. Furthermore, areas of national interest-e.g., natural and cultural environments, recreation, reindeer husbandry, wind and hydro power production, and mineral deposits-should be addressed in the MCP [19,41], often affecting property rights. The same situation applies for the legal rights of reindeer husbandry on all land within the official reindeer herding area, which covers half of Sweden's land area [53].

To conclude, there is a clear link between access to information about forests and the work towards overall sustainable development at the European and Swedish national policy levels. However, when it comes to $\mathrm{MCP}$, as SuD planning at the local level, the relationship between the municipalities and the forest sector (among other land use sectors) is complicated by sectorization, property rights, and other legislation. This causes a hole in the MCP when it comes to basic information about forest conditions and integration of forest land use. The limitation that this has on MCP makes it difficult for the local government to formulate well-informed municipal visions and goals for sustainable forest land use, particularly for forest lands with multiple land use claims, and for overall SuD.

Given the extent and importance of the use of forest lands in Sweden, we intend to illustrate how a local government responsible for territorial SuD by means of spatial planning (including MCP) 
can access relevant knowledge about local forest conditions, forest uses, and its forest owners. Such knowledge is important for improved communication and for informed standpoints throughout the MCP process. Thus, we use data overlay and spatial analysis to produce information and to identify issues related to the use of forest lands of high relevance in the MCP process and to examine how these issues can be addressed. By applying such an approach, we intend to compile, analyze, and communicate the following information:

- Current land ownership patterns: Within a municipality, who owns the forest lands and how much do they own?

- Present forest conditions: How old is the forest and which owner category does the owner belong to? (This information determines how the forest can be used today and by whom.)

- Ecological and social values: Where are the forests located that offer the most significant ecological and social values, and who owns these forests?

Finally, we discuss how information from overlay and spatial analysis of geographical data on forest ownership and forest conditions; the Forest Data Assimilation Approach (FoDAA), can be used and evaluated. We also discuss ways local governments (municipalities) can increase their knowledge about local forest ownership and forest land use. Furthermore, we discuss how methods and knowledge, such as the ones presented in this study, can aid the MCP process.

\section{Materials and Methods}

\subsection{Case Study Area}

Vilhelmina municipality in Västerbotten County in northern Sweden represents forest-dependent northern Swedish municipalities both from a spatial planning perspective and from a land use perspective. Primary laws regulating municipal spatial planning and forestry are the same all over Sweden. From a European perspective, most Swedish municipalities are defined as rural, and in terms of population density Vilhelmina is among the least populated, with less than 1 person $/ \mathrm{km}^{2}$ [54-56]. However, during high season the population in some villages in the mountain region can significantly increase due to tourism and people staying in their second home residences $[57,58]$.

The municipality extends from the Norwegian border in the northwest through high and low mountainous regions, descending to mires and forests in the southeast where about half of the 6700 municipal inhabitants live (almost exclusively in the community center). The municipality covers more than $8700 \mathrm{~km}^{2}$. Almost $670 \mathrm{~km}^{2}$ is water. Mostly located in the western part, $16 \%$ of the municipality area is protected as nature reserves and other types of legal protections. Over $4000 \mathrm{~km}^{2}$ are boreal forest land and of this area $3150 \mathrm{~km}^{2}$ are classified as productive forests cf. [25]. Compilations and analyses for this study are made for the entire municipality as well as for our focus study area, which is in the eastern half of the municipality $\left(4170 \mathrm{~km}^{2}\right.$ of which $2670 \mathrm{~km}^{2}$ is forest land) (Figure 1).



Figure 1. The location of Vilhelmina municipality (Sweden) and our focus study area within the municipality. 
The area has a long history of diverse uses of the forest landscape. The first inhabitants were fishers and hunters tracing back to about 10,000 years ago [59,60]. These people eventually turned to seminomadic reindeer husbandry to make a living [53,61-63]. Today, reindeer husbandry is practiced across Vilhelmina municipality as well as the entire northern half of Sweden. Legally protected, and alongside many other land use forms, reindeer husbandry receives access for grazing on public as well as private land. Incorporating reindeer husbandry into comprehensive land use planning therefore requires a full understanding and evaluation of all forest lands. In addition to reindeer husbandry, Vilhelmina has a tradition of farming. The first farmers settled in the Vilhelmina area in the middle of the 18th century [64]. Eventually, forestry came to dominate the area. Between the 1850s and the 1950s, selective forestry was the common practice since the settlers mainly used the forest for building materials, fuel wood, and grazing [65]. In 1958, the first application for clear cutting was submitted to the Swedish Forest Agency (SFA). Since then, stand replacement forestry followed by intensive reforestation efforts using soil scarification, planting, and sowing have been the common practice and a major industry [65,66]. Large parts of the river system of Ångermanälven within Vilhelmina municipality were affected by timber rafting (until the 1950s) and the construction of hydro power plants and reservoirs (between the early 1940s and the 1980s) [67]. There are a few wind mills (five) in the area, but wind farms with a total of about 200 wind mills are waiting for approval [68,69]. During the 1970s and 1980s, there were some mining activities in the mountain area. Today, there are no active mines, but there are several ongoing explorations [70,71]. Based on property rights and the Right of Public Access, recreational activities such as fishing, hunting, berry picking, snow mobile driving, skiing, and hiking are conducted throughout the area in private as well as commercial contexts [72-76].

\subsection{Geographic Data on Forest Land Use}

Satellite images are useful sources for forest resource assessment in general [77] and archives of satellite imagery can document land use activities. Accordingly, we use changes in satellite imagery to map forest areas that have been subjected to final felling. That is, we use results from a change detection analysis of a time series of satellite images to date forest patches subjected to final felling for the image pairs 1973-1986, 1986-1990, 1990-2000, and 2000-2014 [78]. For the period 1958-1973, this Forest Change Analysis (FCA) was supplemented with other satellite imagery information [79] and data from the National Forest Inventory [80]. Specifics of the process are summarized by Svensson et al. [78]. Based on detected and dated final felling, we know when new forest stands were established and consequently we know the forest age. We compiled such information for all forest land in our focus study area and for different forest owner categories.

Data on forest cover for Vilhelmina municipality was retrieved from the Swedish roadmap (1:100,000) [81]. A property map with property id-numbers was provided by Vilhelmina municipality [82]. Information about forest owners within Vilhelmina municipality was provided by the SFA [83]. The information links forest owners to their properties through property id-numbers and provides general forest owner classification as well as postal codes. We used this information to categorize the forest owners: state, company (i.e., large-scale forest enterprises), community (a large forest common, the municipality, and a few village commons), non-industrial private forest owners (NIPF), and others. The NIPF category was subdivided into resident owners, non-resident owners, and mixed (based on residency within or outside the municipality or if the owners were a mix of both residents and non-residents). The ownership situation reflects the status for January 2016 [81-83].

In our analysis, we included geographic data on formally protected areas to indicate areas of primarily high ecological values. From the County Administrative Board (CAB) [84], we obtained data on nature reserves; from the SFA, we obtained geographic data on forestry-related types of formally protected areas-i.e., biotope protection (biotopskydd) and nature management agreements (naturvårdsavtal) $[85,86]$. Historical or cultural sites in the forest landscape were downloaded from the SFA [87]. Additional data describing ancient monuments and other cultural relics were obtained from the Swedish National History Board (Riksantikvarieämbetet) database Fornsök [88]. In terms of social 
values, Hörnsten and Fredman argue that forest areas within $300 \mathrm{~m}$ and up to $1 \mathrm{~km}$ from residences are the most significant to people [89] as such areas are very likely to be used for recreational purposes like berry and mushroom picking, hiking, and skiing. In this study, we map these areas based on housing data produced by Lantmäteriet and provided by Vilhelmina municipality [90]. Hunting and snowmobiling are recreational activities conducted widely within Vilhelmina Municipality, not just within a kilometer from residences. We obtained non-official digital data of snowmobile tracks on forest land from Vilhelmina municipality. Regarding hunting (large and small game), there were no relevant data available for analyses. Hunting is performed on virtually all land but the hunting season differs depending on the game and is regulated by law [91].

\subsection{Data Overlay}

To meet the municipal need for basic information about forest conditions and ownership status for integration into MCP, we performed several data layer overlays in a geographical information system (ESRI ArcGIS) by means of what we call the Forest Data Assimilation Approach (FoDAA). We combined results from FCA with official property data, information on forest extent, protected areas, historic/cultural sites, and relics and geographic data on permanent and second-home residences and snowmobile tracks (Figure 2). Using this approach, we obtained specific information about the forest and individual forest owners (e.g., forest owner category).

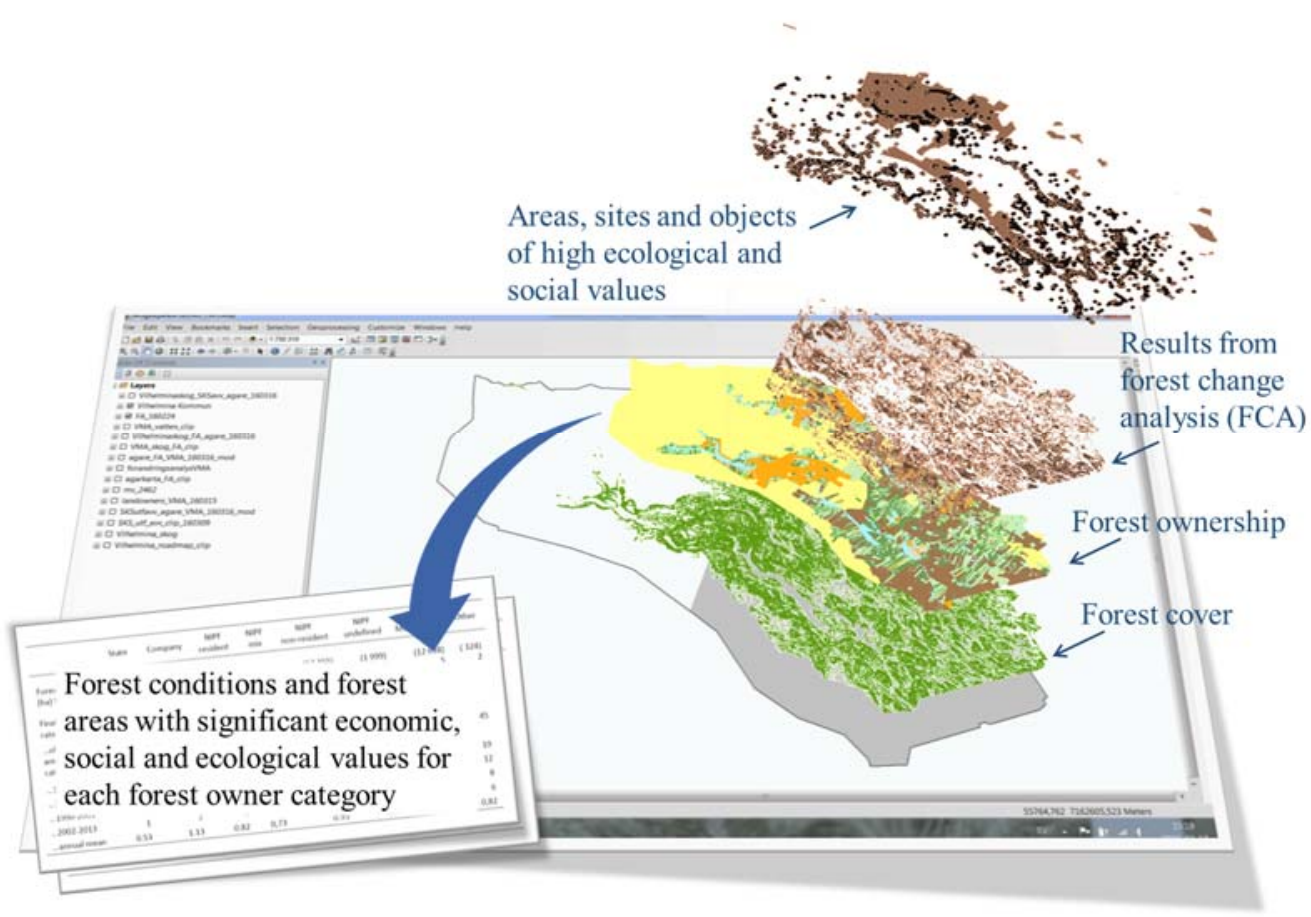

Figure 2. Data overlay procedure. Results from forest change analysis (FCA) in our focus study area in the eastern part of Vilhelmina municipality (Sweden) are combined with information on forest ownership, forest cover, and areas of high ecological and social values in the entire Vilhelmina municipality. This information was used as a base for calculating percentages of forest areas of different ages and values for each forest owner category.

Data overlay was performed for the entire municipality, but the relationship between forests of different ages, protected land, historical sites, and lands of potentially great importance for recreational activities are merely presented for the focus study area, which is in the eastern part of the municipality (Figure 2). Cloud-free satellite images were not available for all time steps in the satellite image time series for the western portion of Vilhelmina municipality, so they were not covered by the FCA [78]. 


\section{Results}

\subsection{Land Ownership Patterns}

By merging information on individual forest owners in different owner categories with their respective forest holdings, we recorded the distribution of land types in Vilhelmina municipality for each owner category (Table 1).

Table 1. Distribution of land cover types (water excluded) for the entire Vilhelmina municipality (entire VMA) of Sweden and our focus study area (focus area) within different forest owner categories. Note that distribution of land between owner categories refers to the situation in January 2016.

\begin{tabular}{|c|c|c|c|c|c|c|c|}
\hline \multirow[t]{2}{*}{ Land Cover } & \multirow{2}{*}{$\begin{array}{c}\text { Entire } \\
\text { VMA } \\
\left(\mathrm{km}^{2}, \%\right)\end{array}$} & \multirow{2}{*}{$\begin{array}{c}\text { Focus } \\
\text { Area } \\
\left(\mathrm{km}^{2}, \%\right)\end{array}$} & \multicolumn{5}{|c|}{$\begin{array}{l}\text { Owner Category * Possession of Land Type } \\
\text { (\% in Entire VMA and in Focus Study Area) }\end{array}$} \\
\hline & & & State & Company & NIPF & Community & Other \\
\hline Sum & 100 & 100 & 16.1 & 30.5 & 42.4 & 4.2 & 6.8 \\
\hline \multirow{2}{*}{ Forest land } & 4064.4 & 2671.6 & 23.2 & 24.1 & 37.5 & 13.0 & 2.1 \\
\hline & 50.0 & 69.1 & 14.9 & 33.2 & 45.0 & 4.7 & 2.1 \\
\hline Wetlands & 20.0 & 28.5 & 20.7 & 30.3 & 43.7 & 3.6 & 1.7 \\
\hline \multirow{2}{*}{ Mountains } & 1298.1 & 0.1 & 99.7 & 0.0 & 0.1 & 0.2 & 0.0 \\
\hline & 16.0 & 0.0 & 15.0 & 0.0 & 75.0 & 0.0 & 0.0 \\
\hline \multirow{2}{*}{ Mountain Birch forests } & 1042.7 & 19 & 93.8 & 0.0 & 4.8 & 1.0 & 0.4 \\
\hline & 12.8 & 0.5 & 88.1 & 0.0 & 11.9 & 0.0 & 0.0 \\
\hline Open lands & 87.8 & 68.9 & 3.9 & 6.4 & 74.6 & 2.4 & 12.8 \\
\hline
\end{tabular}

* Land ownership is categorized as State, Company (large-scale forest companies), Non-industrial private forest owners identified as living in or outside the municipality (NIPF), Community (a large forest common, the municipality, and some smaller village commons), and Other (the church, foundations, and unidentified owners).

Land cover types and land ownership patterns differ significantly between the Vilhelmina municipality area and our focus study area. The proportion of non-forest land (mostly mountains) and the proportion of state-owned lands are higher for the entire municipality. Conversely, the proportion of forest land, the proportion of NIPF, and the proportion of company-owned lands is much higher in our focus study area (Figure 3).

\section{Forest ownership (\%)}

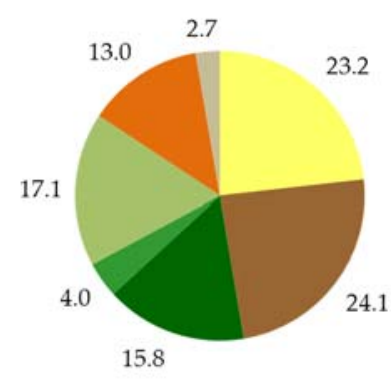

(a) Entire Vilhelmina municipality

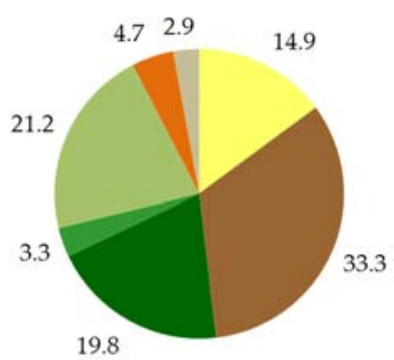

(b) Focus study area



= Other

Figure 3. The distribution of forest lands by owner categories for (a) the entire Vilhelmina municipality (Sweden) and (b) for our focus study area as of January 2016. Land ownership is categorized into State, Company (large-scale forest companies), NIPF resident and NIPF non-resident (non-industrial private forest owners identified as living in or outside the municipality), NIPF mix (a mix of NIPF resident and NIPF non-resident owners), Community (a large forest common, the municipality and some smaller village commons), and Other (the church, foundations, and unidentified owners). 
Figure 4 depicts maps of land cover types and ownership patterns in Vilhelmina municipality. The state is the largest single landowner in Vilhelmina municipality and most lands owned by the state and by communities are found in the northwest (Figure $4 b$ ).

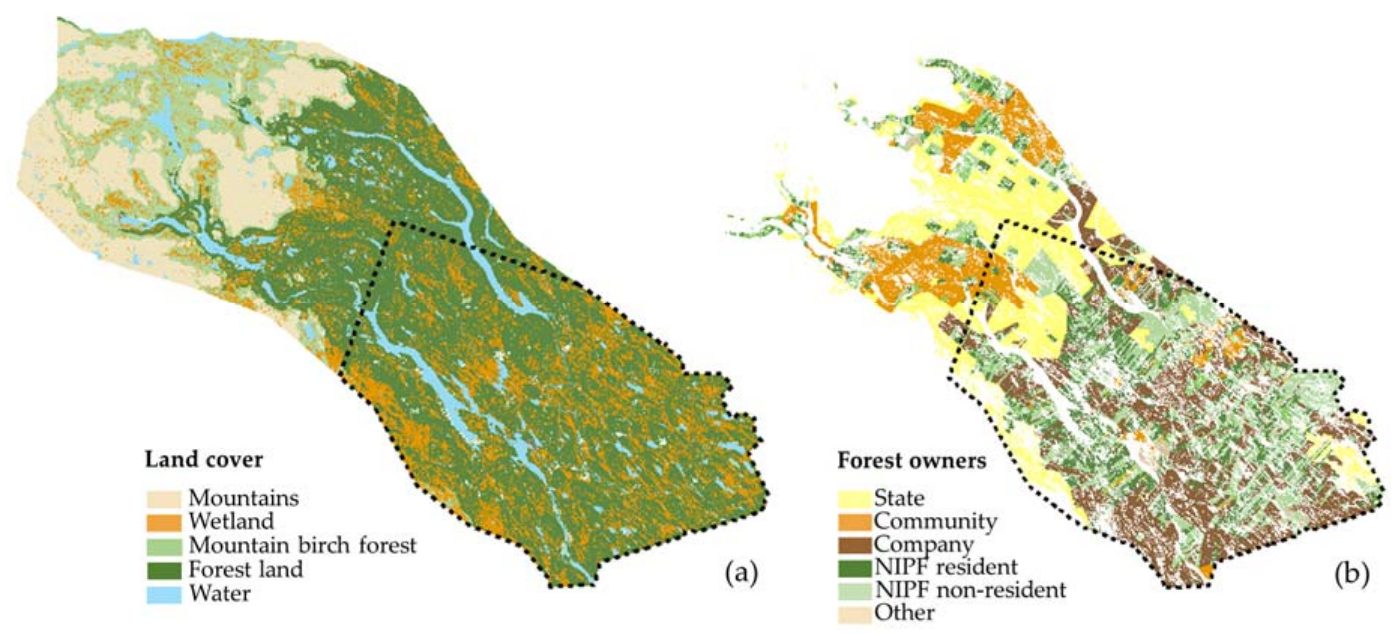

Figure 4. Maps of Vilhelmina municipality (Sweden) illustrating (a) major land cover types and (b) forest ownership patterns (as of January 2016), with a separation of resident and non-resident NIPF owners. The dotted line marks our focus study area. Land ownership is categorized into State, Company (large-scale forest companies), NIPF resident and NIPF non-resident (non-industrial private forest owners identified as living in or outside the municipality), NIPF mix (a mix of NIPF resident and NIPF non-resident owners), Community (a large forest common, the municipality, and some smaller village commons), and Other (the church, foundations, and unidentified owners).

\subsection{Forest Conditions}

Based on dated final felling events detected from the FCA, we present a dataset describing forest age for all forest land independent of forest owner for our focus study area. Such full cover and accurate information about forest age requires satellite time-series analysis and could not be produced by single image optical satellite images nor by laser scanning. We combined the information depicting forest age with land owner information and revealed large variations in distribution of forest age classes between the different owner categories (Figure 5). A large part of the forest that was final felled between 44 and 58 years ago is owned by companies and non-resident NIPF owners and there is also a large proportion of NIPF forests, as well as company forests, that are $27-43$ years old. NIPF owners hold about twice as much (21\%) of the non-final felled forests ( $>58$ years old forests) as companies and the state, who hold $11 \%$ and $13 \%$, respectively. Before applying the FCA, such information only existed for some industrial timber lands and was not available for organizations such as municipalities.

Of the company-owned forests, $62 \%$ are younger than 58 years as of today. The corresponding number for state-owned forests is $29 \%$. NIPF forest lands show a more even age distribution, but there is a surprisingly large variation in forest age among the different NIPF owner categories. Non-residents own a larger area of forests 58 years old or younger (51\%) than resident owners (45\%). Consequently, the proportion of forest land for the different forest owner categories that has not been subjected to final felling between 1958 and 2013 (i.e., >58 years) are lowest on company land (38\%), followed by non-resident NIPF, and community-owned land (49\%). The resident NIPF owners have $55 \%$ of forests $>58$ years of age and on state-owned land it is $71 \%$ (Figure 6). 


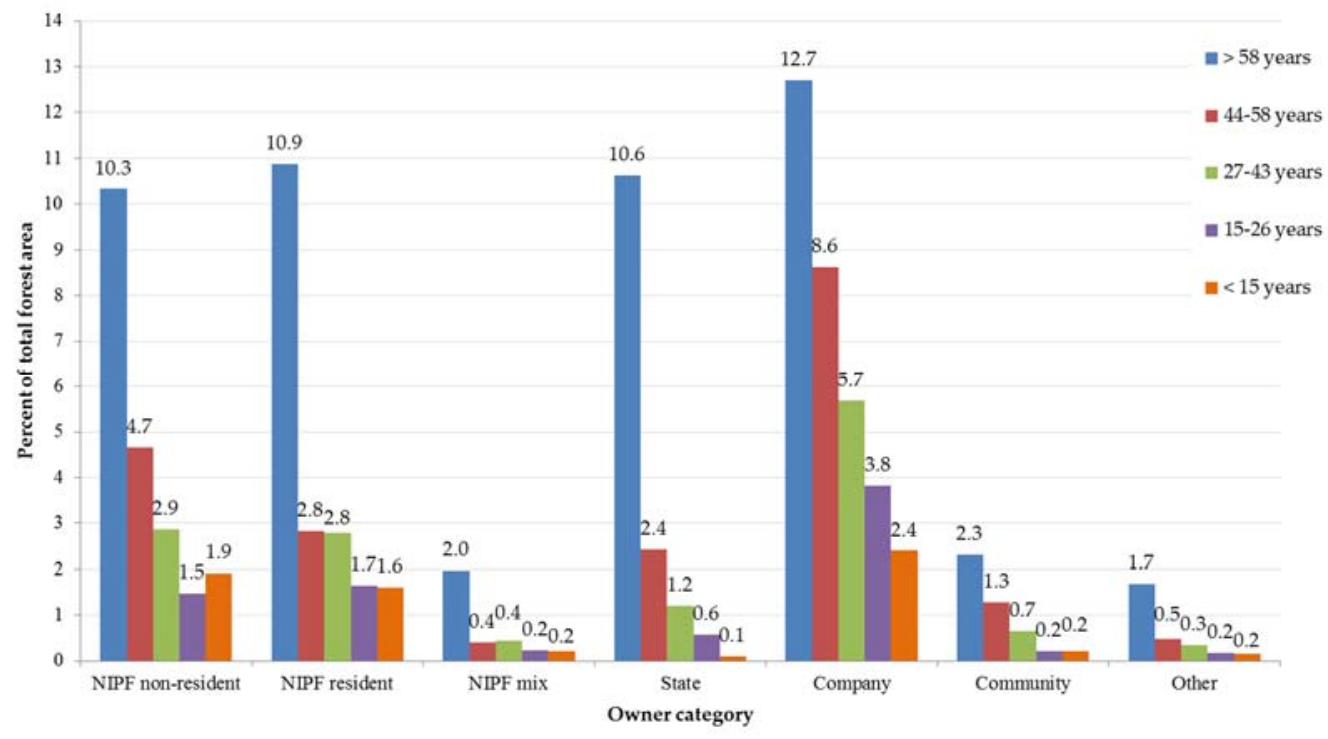

Figure 5. Distribution of the total forest area $\left(2674 \mathrm{~km}^{2}\right)$ among owner categories in our focus study area within Vilhelmina municipality, Sweden. The distribution is presented in intervals of forest age: from $>58$ years old (not subjected to final felling) to $<15$ years. Note that data on owner category refers to the situation in January 2016. Land ownership is categorized into State, Company (large-scale forest companies), NIPF resident and NIPF non-resident (non-industrial private forest owners identified as living in or outside the municipality), NIPF mix (a mix of NIPF resident and NIPF non-resident owners), Community (a large forest common, the municipality, and some smaller village commons) and Other (the church, foundations, and unidentified owners).

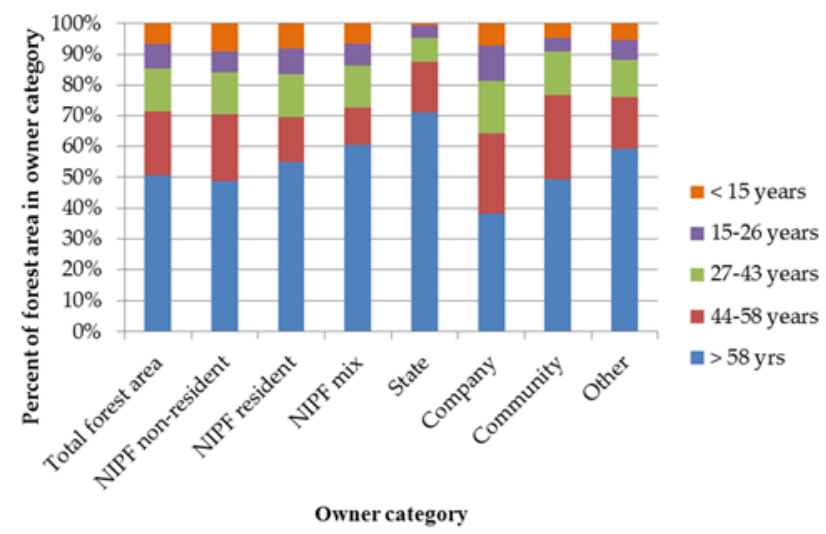

Figure 6. The distribution of forest age within forest owner categories in our focus study area within Vilhelmina municipality, Sweden. Note that data on owner category refers to the situation in January 2016. Land ownership is categorized into State, Company (large-scale forest companies), NIPF resident and NIPF non-resident (non-industrial private forest owners identified as living in or outside the municipality), NIPF mix (a mix of NIPF resident and NIPF non-resident owners), Community (a large forest common, the municipality, and some smaller village commons) and Other (the church, foundations, and unidentified owners).

\subsection{Significant Values in the Forest}

For the entire Vilhelmina municipality, forests that are formally protected because of their high ecological values encompass $476.3 \mathrm{~km}^{2}$ or $12 \%$ of all forest land. In our focus study area, $179.9 \mathrm{~km}^{2}$, or $7 \%$, of the forests are protected. Among the protected forest lands, $85 \%$ have not been subjected to final felling, $13 \%$ are in the $44-58$ year age category, and $2 \%$ are in the $27-43$ year age category. Most 
protected areas (94\%) are owned by the state. The forestry-related protected areas (biotope protection and nature management agreements) represent less than $2 \mathrm{~km}^{2}$ in total. However, resident owners own twice as much of these protected areas than the non-resident owners. To explain this notable situation, further investigation is needed.

There are 1502 historical and culturally valuable objects and sites recorded by the Swedish National Heritage Board and the SFA on forest land in Vilhelmina municipality. Most of these forests have not been subjected to final felling during the last 58 years (Table 2).

Table 2. Historically and culturally valuable objects and sites in forests of different ages in the entire Vilhelmina municipality (Sweden) and in our focus study area. The objects and sites are recorded as points, lines, and areas.

\begin{tabular}{|c|c|c|c|c|}
\hline & & \multicolumn{3}{|c|}{ Historical/Cultural Sites in Forest } \\
\hline & & Points (Number) & Lines (km) & Areas $\left(\mathrm{km}^{2}\right)$ \\
\hline \multirow{2}{*}{ Study Area: } & Entire Municipality: & 985 & 10.76 & 16.7 \\
\hline & Focus Area: & 747 & 8.71 & 16.2 \\
\hline \multirow{5}{*}{$\begin{array}{l}\text { Forest Age in } \\
\text { Focus Area: }\end{array}$} & >58 years: & 504 & 5.53 & 10.6 \\
\hline & $44-58$ years: & 105 & 0.78 & 2.4 \\
\hline & 27-43 years: & 64 & 1.10 & 2.9 \\
\hline & 15-26 years: & 43 & 0.39 & 0.1 \\
\hline & <15 years: & 31 & 0.91 & 0.2 \\
\hline
\end{tabular}

There are $1438 \mathrm{~km}$ of snowmobile tracks in the entire municipality of which $637 \mathrm{~km}$ are located within our focus study area. On public and private forest land, respectively, $420 \mathrm{~km} \mathrm{(29 \% )} \mathrm{and} 233 \mathrm{~km}$ $(37 \%)$ are found. Most tracks are found in forests $>58$ years (57\%), 19\% are found in 44-58-year-old forests and $14 \%$ in $27-43-y e a r-o l d$ forests. Less than $11 \%$ of the tracks are found in forests younger than 26 years.

In the entire municipality of Vilhelmina, $1347 \mathrm{~km}^{2}$ of the forest land are of high social value in terms of high potential use for recreational purposes due to the proximity to residences $(<1 \mathrm{~km})$. In our focus study area, this area constitutes $895.9 \mathrm{~km}^{2}$, where $51 \%$ is found in forests not subjected to final felling, 19\% in 44-58-year-old forests, 14\% in 27-43-year-old forests, 9\% in 15-26-year-old forests and $8 \%$ in forests younger than 15 years. A majority (65\%) of the forest land within $1 \mathrm{~km}$ from residences are NIPF ( $31 \%$ is owned by NIPF resident owners and $27 \%$ by NIPF non-resident owners). Companies own $26 \%$ of the forest land within $1 \mathrm{~km}$ of residences (Table 3 ).

Table 3. Areas within $1 \mathrm{~km}$ from residences per forest owner category in Vilhelmina municipality (Sweden) and in our focus study area. Land ownership is categorized in State, Company (large-scale forest companies), NIPF resident and NIPF non-resident (non-industrial private forest owners identified as living in or outside the municipality) and NIPF mix (a mix of NIPF resident and NIPF non-resident owners), Community (a large forest common, the municipality, and some smaller village commons), and Other (the church, foundations, and unidentified owners).

\begin{tabular}{|c|c|c|c|c|c|c|c|}
\hline & & \multicolumn{6}{|c|}{ Forest Areas within $1 \mathrm{~km}$ from Residences } \\
\hline & & \multirow{2}{*}{$\begin{array}{l}\text { ( } \mathrm{km}^{2} \text { in Study Area, \% of Focus } \\
\text { Area per Forest Age Interval) }\end{array}$} & \multicolumn{5}{|c|}{ ( $\%$ of Study Area per Owner Category) } \\
\hline & & & State & Company & NIPF & Community & Other \\
\hline \multirow{2}{*}{ Study Area: } & Entire Municipality: & 1347.1 & 8.0 & 19.3 & 58.4 & 10.9 & 3.3 \\
\hline & Focus Area: & 895.9 & 2.5 & 26.1 & 64.5 & 3.9 & 3.0 \\
\hline \multirow{5}{*}{$\begin{array}{l}\text { Forest Age in } \\
\text { Focus Area: }\end{array}$} & $>58$ years: & 50.7 & 1.6 & 9.3 & 36.0 & 2.0 & 1.9 \\
\hline & $44-58$ years: & 19.2 & 0.4 & 7.1 & 10.3 & 0.9 & 0.5 \\
\hline & $27-43$ years: & 13.7 & 0.3 & 4.4 & 8.1 & 0.5 & 0.4 \\
\hline & 15-26 years: & 8.5 & 0.2 & 3.3 & 4.6 & 0.3 & 0.2 \\
\hline & <15 years: & 7.9 & 0.1 & 2.1 & 5.4 & 0.2 & 0.1 \\
\hline
\end{tabular}




\section{Discussion}

\subsection{Land Ownership Patterns}

According to Swedish acquisition law and established practice, juridical persons (e.g., forest companies and the state) have very limited possibilities to buy new forest land from private individuals unless they sell off an equivalent piece of land to private individuals [92]. Thus, we assumed that the land recorded as owned by the state and by companies in 2016 also was the amount of state- and company-owned land in 1958. An exception is the lands of the state-owned company Sveaskog. The company can be assumed to act as any other large-scale forest company, but in 2002 the owner (the state) decided that Sveaskog should sell $10 \%$ of its lands to promote private agriculture and farming [93-95]. The preconditions for the selling have changed somewhat since 2002, but as of November 2016 Sveaskog has sold approximately 8\% of its total land in Sweden, approximately 9\% in the county of Västerbotten, and slightly more than $20 \%$ in Vilhelmina municipality [96]. An overall stable ownership pattern applies to the NIPF owner category. However, within the NIPF owner category, largely due to the out-migration of people from Vilhelmina from 1958 [55,56], it can be assumed that a substantial proportion of the forest land owned by resident owners in 1958 is now owned by non-residents, while the forest land owned by resident owners in 1958 is still owned by resident owners. Considering results from studies on ownership and migration [97], it is surprising that only $3 \%$ of the forest land is owned by a mix of non-residents and residents.

\subsection{Forest Conditions}

Before 1958, the general forestry practice in Vilhelmina was selective harvest $[65,66]$. Therefore, large parts of company-, state-, and community-owned forest land had low stocks. The FCA shows a large portion of forests of 44-58 years of age, which reflect the extensive restoration of understocked stands that took place between the 1950s and the 1980s. Large areas were first clear cut and then regenerated (or at least this was attempted) by planting or sowing. Driven by their interest of securing long-term supplies of timber, forest companies were the first to phase out their low stocked stands, while many NIPF owners needed to be incentivized by state subsidies offered during the 1980s [98]. The apparent difference in forest age distribution between the different NIPF categories, indicating different management behaviors, is harder to explain. More information is needed to explain the relation between residency and management practice. This kind of knowledge-i.e., who owns what forest land and how the forest lands are likely to be managed-would help municipalities to strategically plan housing developments, industrial exploitation (mines, power production, etc.), and safeguards for ecological and social values in the forest landscape.

\subsection{Significant Values in the Forest}

In Sweden, most protected forest area is state-owned nature reserves. The reserves aim to protect larger areas with high values related to biodiversity, geography, scenery, recreation, etc. The monopoly regarding spatial planning, with $\mathrm{MCP}$ as a base, puts a vast responsibility on municipalities to safeguard national interests and to fulfill national environmental quality goals. Among other things, MCP must address the protection of forest land and its different values [99]. Our study shows that most forest areas with significant cultural/historical or recreational values have not been subjected to final felling (i.e., $>58$ years old). However, our results do not explain why this is so. Olsson illustrates the importance of proximity to urban areas to explain frequently used forests and the importance of urban fringe forests $[100,101]$. These findings mean that municipalities need to keep informed not only about existing forest protection but also about various recorded and experienced values in the forest landscape related to where people would like to live and conduct various recreational activities. Without this knowledge, it is not possible to have a grounded opinion about further protection or to make statements or priorities concerning development strategies and changes in land use on forest land. 


\subsection{Data Overlay and Spatial Analysis}

Vilhelmina represents a suitable case study in terms of evaluating MCP as a planning tool for SuD. The laws and regulations regarding MCP are the same for all Swedish municipalities. Furthermore, land use and forests in Vilhelmina have been studied and described from various perspectives over the years cf. $[25,66,67,102-111]$. This history gives a unique opportunity to combine and compare information from our study with other research to further analyze and learn about local forests from a municipal perspective.

Apart from the FCA, the municipality already has access to all demographic and geographic information we used for our analysis in this study. However, because the data are not structured in a way that easily allows for the FoDAA, municipalities have not been able to take advantage and analyze available data. Today, the access to FCA is still limited for other municipalities, but geographic data on forest change in terms of final felling since 2002 are available from the SFA website. This access makes it possible for any municipality to start building their forest land use history, and hopefully more historical data can be provided in the near future as well. A more tangible problem is the generally-known shortage in municipal resources for spatial planning such as MCP cf. [47,112-114]. Although analyzing how to coordinate land use interests and land use planning is not within the scope of this paper, it is important to consider whether municipalities should conduct the FoDAA themselves or if it should be done on a national/regional level and then be provided to the municipalities. This is an approach that resembles how geographic data and other vital information for planning are provided by CABs regarding other types of land use.

\subsection{The Aids of Integrating Geographic Forest Data in MCP}

In Sweden, municipalities, with some exceptions (e.g., forestry and mining), have had the major responsibility for territorial land use planning and decisions. The degree of local self-governance is rather unique in an international perspective. In most other industrialized countries, the regional level is more apparent. However, forests and forestry have not been an obvious part of the Swedish MCP. Today, the municipal spatial planners most likely are unaware if, how, or why they should integrate forest and forest land use in MCP cf. [47].

General lack of resources for MCP [47] and the rather unclear mix of sectorial and territorial planning in MCP are major barriers to implementing MCP and incorporating forest land use in the planning process. Property rights are sometimes understood as a barrier [43], but this is a misinterpretation. To include a land use interest in the public planning process does not imply that the land automatically will be controlled or that the property rights will be challenged by the planning authority. In fact, including forest land into the formal MCP process could expand property rights. We argue that the FoDAA provides a piece in the spatial planning puzzle that is missing. The picture of the local forest and its owners is important new knowledge for MCP. Furthermore, one might say that forest land is already included in MCP. The forest owners engage in enterprises considered to be very important for the national forest industry. Depending on where they live and how they manage their forest, the forest owners also contribute to and affect the local society through their management of the landscape, local trade, and taxes. Closer cooperation and concerted planning would offer a better overview of the forest as a locally as well as a nationally important resource. Forest land is also affected by some of the national and public interests that should be considered in MCP (e.g., national interest of nature management, recreation, and tourism and, in the north, the national interest of reindeer husbandry as well as the legally required planning for rural development in watershed areas). The ongoing forestry activities are not affected by the national interests, but if forest owners wish to switch to another land use form and/or to build something in a watershed area that is not considered to be of general importance to rural development, their property rights are not very strong. The forest owners also have a rather relaxed relation to the public using their land in accordance to the Right of Public Access [115]. This custom is beneficial for forest owners as well because it grants access to other owners' lands. However, the MCP is meant to be a strategic tool for sustainable land use and 
development on the territorial level, which means that the local government should express where and how different types of land use should be carried out within the municipality borders. Some of these land uses, such as tourism, lean on the Right of Public Access. Extensive forestry activities, such as final felling, are often perceived as having a negative effect on social (and ecological) values of the forest land. On the other hand, thinning (carried out two or three times during a rotation cycle of about 100 years) can be considered to improve the accessibility and the social values of the forest. Furthermore, the network of forest roads increases the access in the landscape for the general public as well as for commercial activities. In sum, the municipal planning for other uses of the forest land could affect the lands of various forest owners and their possibility to use or not use the land in the way that they wish.

Supplementing MCP with data on forest and forest owners also improves preconditions for communication in the planning process. With forests and forest land use added to the overall map of land use, the local government (in our case the municipality) has a better point of departure for dialogue with forest owners (as well as other land use actors and authorities). The FoDAA provides a common base and a communicative tool. Using the FCA to identify if forests have been subjected to final felling also provides a time perspective to the tool. The FoDAA can be used in discussions and possibly for co-production of new and more in-depth knowledge about forest values and about the needs and desires of the users, including the forest owners, of forest land considered in MCP. Moreover, the FoDAA can be used on the property level or over larger areas, such as a region or a country, a flexibility that enables the scale up or down in level of detail as well as geography. This advantage offers governmental agencies and other types of actors in different sectors on different societal levels the same knowledge and ensures that they all refer to the same facts even though it can be presented with various resolutions. Extensive and shared knowledge on forest land use is undoubtedly important for successful communication and cooperation between actors in different sectors [76]. Hence, assimilation of geographic data of good quality on forest land use in MCP could improve the prospect of anticipating and avoiding local land use conflicts.

\section{Conclusions}

Various types of land use, as well as formal decisions, can affect large geographic areas more or less independent of land cover types, forest conditions, and ownership boundaries. In Sweden, land use without boundaries includes all land uses related to grazing rights in reindeer husbandry, the Right of Public Access, the appointment and application of national interests (Riksintressen), and various environmental issues. The necessity of data without boundaries in MCP, as local spatial planning in a sustainable development context, becomes apparent. In this paper, we have argued for a better integration of forest land use as well as information about forests in MCP. We introduced the notion of a hole in the MCP land use map regarding basic information about forest conditions, forest owners, and forest land use. In our focus area, the size of this hole represents $64 \%$ of the territory (and $46 \%$ in the entire municipality). By applying the Forest Data Assimilation Approach, we have shown that ownership probably affects forest conditions, in this case, specifically in terms of when and where final felling has been carried out and hence the age of the forest and where the remaining non-final felled forests are found. Although knowledge about the proportion and location of forests of different ages is certainly valuable information, even more important knowledge is the specific location of forests with certain qualities, indicated by their age, by their ownership, and by their significant social, historical, and ecological values (Figure 7). Furthermore, land uses and rights such as reindeer husbandry and the Right of Public Access span most types of land including the forest land hole. With such land uses in practice, the need for an accurate description of the hole increases. 




(a) Forest land

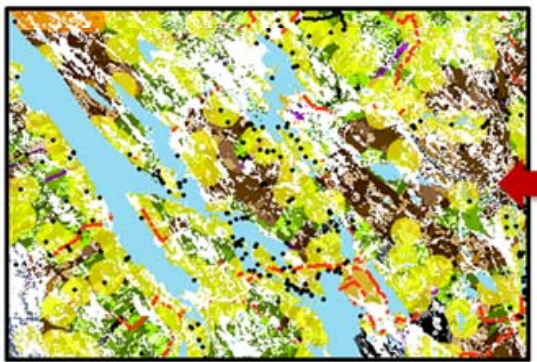

(d) Forests of various age by ownership with land use information

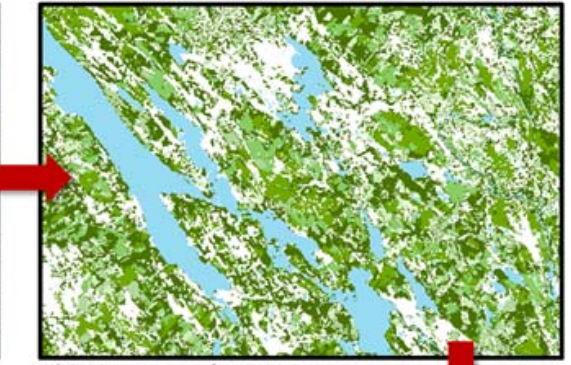

(b) Forests of various age

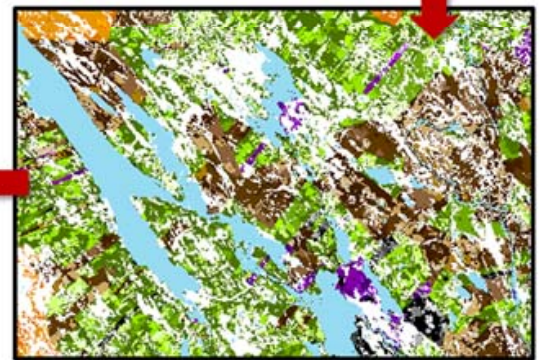

(c) Forests of various age by ownership

Figure 7. Maps illustrating the results from the Forest Data Assimilation Approach for our focus study area in Vilhelmina municipality, Sweden: (a) proportion and location of forest land; (b) area and location of forest land of various ages and thereby character; (c) area and location of forest land of various ages by ownership; and (d) area and location of forest land of various ages by ownership with information about the use of forest land for various purposes.

Our study demonstrates that spatial analysis and overlay of geographic forest data and forest owner information according to the FoDAA can provide opportunities to view forest property and the individual forest owner in a landscape perspective. This approach provides a picture of forest ownership and the relationship between forest owners and their forests, making it possible to analyze the forest assets and the joint activity of different owner categories in relation to each other and to conditions for forest land use associated with ecological, social, and economic values of the forest. Our approach creates a visible link from the individual forest owner and his/her forest to planning and decision-making organs of society at different levels. The approach allows us to learn from the past to better plan for the future. It can place the forest owner and forest land use on the map in time and space. This perspective is vital to a planning process that aims to make way for and balance different land use interests in a given landscape in a sustainable manner cf. [111]. There are of course challenges to overcome in this balancing act, among them the capacity of local (municipal) planning, lack of resources for planning, and the coordination of multi-level governance (local level versus central level). However, we have shown that it should be possible to improve the holistic perspective in municipal comprehensive planning with available data. Hence, the outcome of the planning process is more likely to consider and balance the needs of all municipal (local) inhabitants and businesses, including forest owners and forest enterprises, and at the same time consider regional and national policies and goals. What the achieved information says about previous and current land use, including potential future claims or expectations, will increase the municipalities' space of action, competence, and capacity to take planning actions towards sustainable development.

Acknowledgments: This research was performed within the PLURAL project (Planning for Rural-Urban Dynamics: Living and Acting at Several Places) and funded by the Swedish Research Council Formas. We thank Jon Andersson at SLU, Maria Eriksson at Vilhelmina Municipality and Håkan Persson at the Swedish Forest Agency in Vilhelmina for preparing and providing input data. 
Author Contributions: C.T., G.L. and P.S. contributed to the study design. C.T. performed the analyses and compiled the results. C.T., G.L. and P.S. interpreted the results. C.T. prepared the manuscript with O.S. and G.L. specifically contributing to the introduction and to the discussion and conclusion of the paper.

Conflicts of Interest: The authors declare no conflict of interest.

\section{References}

1. World Commission on Environment and Development (WCED). Our Common Future; Oxford University Press: Oxford, UK, 1987; p. 383.

2. United Nations (UN). Agenda 21: Programme for Action for Sustainable Development: Rio Declaration on Environment and Development: Statement of Forest Principles: The Final Texts of Agreements Negotiated by Governments at the United Nations Conference on Environment and Development (UNCED), 3-14 June 1992, Rio de Janeiro, Brazil; UN: New York, NY, USA, 1994; p. 294. ISBN 92-1-100509-4.

3. United Nations Environmental Programme (UNEP). Agenda 21; UNEP: New York, NY, USA, 2000.

4. Eckerberg, K.; Dahlgren, K. Project or Process? Fifteen years' experience with Local Agenda 21 in Sweden. Economiaz Rev. Vasca Econ. 2007, 64, 124-141.

5. Baker, S.; Eckerberg, K. Introduction: In pursuit of sustainable development at the sub-national level: The 'new' governance agenda. In Pursuit of Sustainable Development: New Governance Practices at the Sub-National Level in Europe; Baker, S., Eckerberg, K., Eds.; Taylor \& Francis Group: New York, NY, USA, 2008; pp. 1-26.

6. Sobol, A. Governance barriers to local sustainable development in Poland. Manag. Environ. Q. 2008, 19, 194-233. [CrossRef]

7. Andersson, K.; Angelstam, P.; Axelsson, R.; Elbakidze, M.; Törnblom, J. Connecting municipal and regional level planning: Analysis and visualization of sustainability indicators in Bergslagen, Sweden. Eur. Plan. Stud. 2013, 21, 1210-1234. [CrossRef]

8. Wilson, I. Strategic planning isn't dead-It changed. Long Range Plan. 1994, 27, 12-24. [CrossRef]

9. Mintzberg, H. The fall and rise of strategic planning. Harv. Bus. Rev. 1994, 72, 107-114.

10. Faludi, A. The performance of spatial planning. Plan. Pract. Res. 2000, 15, 299-318. [CrossRef]

11. Montin, S.; Johansson, M.; Forsemalm, J. Understanding innovative regional collaboration. In Public Innovation through Collaboration and Design; Ansell, C., Torfing, J., Eds.; Routledge: Abingdon, UK; New York, NY, USA, 2014; pp. 106-124.

12. European Commission. ESDP European Spatial Development Perspective. Towards Balanced and Sustainable Development of the Territory of the European Union; Office for Official Publications of the European Communities, European Commission: Luxembourg, 1999; ISBN 92-828-7658-6.

13. European Landscape Convention. European Treaty Series; No. 176; Council of Europe: Gödöllö, Hungary, 2000.

14. Healey, P. The Revival of Strategical Spatial Planning in Europe. In Making Strategical Spatial Plans: Innovations in Europe; Healy, P., Khakee, A., Motte, A., Needham, B., Eds.; Routledge: London, UK, 2003; pp. 3-19.

15. Territorial agenda of the European Union 2020. Towards an inclusive, smart and sustainable Europe of diverse regions. In Agreed at the Informal Ministerial Meeting of Ministers Responsible for Spatial Planning and Territorial Development on 19th May 2011; Council of Europe: Gödöllö, Hungary, 2011; p. 10.

16. Albrechts, L. Strategic (spatial) planning reexamined. Environ. Plan. B 2004, 31, 743-758. [CrossRef]

17. Koschke, L.; van der Meulen, S.; Frank, S.; Schneidergruber, A.; Kruse, M.; Fürst, C.; Neubert, E.; Ohnesorge, B.; Schröder, C.; Müller, F.; et al. Do you have 5 minutes to spare?-The challenges of stakeholder processes in ecosystem services studies. Landsc. Online 2014, 37, 1-25. [CrossRef]

18. Elbakidze, M.; Dawson, L.; Andersson, K.; Axelsson, R.; Angelstam, P.; Stjernquist, I.; Teitelbaum, S.; Schlyter, P.; Thellbro, C. Is spatial planning a collaborative learning process? A case study from a rural-urban gradient in Sweden. Land Use Policy 2015, 48, 270-285. [CrossRef]

19. Plan- och Bygglag [Planning and Building Act] 2010:900. Available online: http://www.notisum.se/rnp/ sls/lag/20100900.htm (accessed on 30 May 2017).

20. Sayer, J.; Sunderland, T.; Ghazoul, J.; Pfund, J.-L.; Sheil, D.; Meijaard, E.; Venter, M.; Boedhihartono, A.-K.; Day, M.; Garcia, C. Ten principles for a landscape approach to reconciling agriculture, conservation, and other competing land uses. Proc. Natl. Acad. Sci. USA 2013, 110, 8349-8356. [CrossRef] [PubMed] 
21. Översiktsplanens Innehåll [The content of a Municipal Comprehensive Plan]. Available online: http:/ / www.boverket.se/sv/PBL-kunskapsbanken/oversiktsplan/oversiktsplanens-funktion/ oversiktsplanens-innehall/ (accessed on 22 September 2016).

22. State of Europe's Forests 2015. In Proceedings of the Forest Europe, Ministerial Conference on the Protection of Forests in Europe, Madrid, Spain, 20-21 October 2015.

23. Pulla, P.; Schuck, A.; Verkerk, P.J.; Lasserre, B.; Marchetti, M.; Green, T. Mapping the Distribution of Forest Ownership in Europe; EFI Technical Report 88; European Forest Institute: Joensuu, Finland, 2013.

24. Holmgren, E.; Lidestav, G.; Kempe, G. Forest Condition and Management in Swedish Forest Commons. Small Scale For. Econ. Manag. Policy 2004, 3, 453-468.

25. Eggers, J.; Holmström, H.; Lämås, T.; Lind, T.; Öhman, K. Accounting for a Diverse Forest Ownership Structure in Projections of Forest Sustainability Indicators. Forests 2015, 2015, 4001-4003. [CrossRef]

26. Živojinović, I.; Weiss, G.; Lidestav, G.; Feliciano, D.; Hujala, T.; Dobšinská, Z.; Lawrence, A.; Nybakk, E.; Quiroga, S.; Schraml, U. Forest Land Ownership Change in Europe. COST Action FP1201 FACESMAP Country Reports. Joint Volume; EFICEEC-EFISEE Research Report; University of Natural Resources and Life Sciences: Vienna, Austria, 2015; p. 693.

27. Alarcón Ferrari, C. Forests at the Limits. Ph.D. Thesis, Swedish University of Agricultural Sciences, Uppsala, Sweden, 2015.

28. Holmgren, S. Governing Forests in a Changing Climate. Ph.D. Thesis, Swedish University of Agricultural Sciences, Uppsala, Sweden, 2015.

29. Törnqvist, T. Skogsrikets Arvingar. En Sociologisk Studie av Skogsägarskapet Inom Privat, Enskilt Skogsbruk; Sveriges Lantbruksuniversitet, Institutionen för Skog-Industri-Marknad Studier, Rapport nr 4; Swedish University of Agricultural Sciences (SLU): Uppsala, Sweden, 1995; p. 455. (In Swedish)

30. Vem Äger Skogen? Available online: http://www.skogsstyrelsen.se/Upptack-skogen/Skog-i-Sverige/ Fakta-om-skogen/Vem-ager-skogen/ (accessed on 15 September 2016).

31. Lindgren, U.; Pettersson, Ö.; Jansson, B.; Nilsagård, H. Skogsbruket i den lokala ekonomin Rapport 2000:4; Skogsstyrelsen: Jönköping, Sweden, 2000.

32. Hyttinen, P.; Niskanen, A.; Ottitsch, A. New challenges for the forest sector to contribute to rural development in Europe. Land Use Policy 2000, 17, 221-232. [CrossRef]

33. Elands, B.H.M.; Wiersum, K.F. Forestry and rural development in Europe: An exploration of socio-political discources. For. Policy Econ. 2001, 3, 5-16. [CrossRef]

34. Slee, B. Social indicators of multifunctional rural land use: The case of forestry in the UK. Agric. Ecosyst. Environ. 2006, 120, 31-40. [CrossRef]

35. Thellbro, C. Local Natural Recourse Dependency in a Swedish Boreal Municipally Context. Master's Thesis, Faculty of Forest Sciences, Department of Forest Resource Management and Geomatics, Swedish University of Agricultural Sciences, Umeå, Sweden, 2006.

36. Haugen, K.; Lindgren, U. On the importance of forest assets for micro-firm performance. Fennia 2013, 191, 122-142. [CrossRef]

37. Lidestav, G.; Nordfjell, T. A conceptual model for understanding social practices in family forestry. Small Scale For. 2006, 4, 391-408.

38. Lidestav, G.; Arvidsson, A.-M. Member, Owner, Customer, Supplier?-The Question of Perspective on Membership and Ownership in a Private Forest Owner Cooperative. In Global Perspectives on Sustainable Forest Management; Okia Clement, A., Ed.; InTech: Rijeka, Croatia, 2012; pp. 75-94. [CrossRef]

39. Swedish Forest Agency. Swedish Statistical Yearbook of Forestry 2014; Swedish Forest Agency: Jönköping, Sweden, 2014.

40. Skogsvårdslag [Forestry Act] 1979:429. Available online: http://www.notisum.se/rnp/sls/lag/19790429. HTM (accessed on 30 May 2017).

41. Miljöbalken [Environmental Code] 1998:808. Available online: http://www.notisum.se/rnp/sls/lag/ 19980808.HTM (accessed on 30 May 2017).

42. Regeringens Proposition 1997/98:90. Följdlagstiftning till Miljöbalken m.m. 1998. Available online: https://www.riksdagen.se/sv/dokument-lagar/dokument/proposition/foljdlagstiftning-tillmiljobalken-mm_GL0390/html (accessed on 30 May 2017).

43. Stjernström, O.; Karlsson, S.; Pettersson, Ö. Skogen och den kommunala planeringen. Plan 2013, 1, 42-45. 
44. Hörnsten, L. Outdoor Recreation in Swedish Forests-Implications for Society and Forestry. Ph.D. Thesis, Swedish University of Agricultural Sciences, Uppsala, Sweden, 2000; p. 169.

45. Rydberg, D. Skogens Sociala Värden; Rapport 2001:8; Skogsstyrelsen: Jönköping, Sweden, 2001.

46. Rydberg, D.; Aronsson, M. Vår Tätortsnära Natur-En bok om Förvaltning och Skötsel; Skogsstyrelsens Förlag: Jönköping, Sweden, 2004.

47. Bjärstig, T.; Thellbro, C.; Stjernström, O.; Svensson, J.; Sandström, C.; Sandström, P.; Zachrisson, A. Between protocol and reality-Swedish municipal comprehensive planning. Eur. Plan. Stud. 2017, submitted.

48. Kløcker Larsen, R.; Raitio, K.; Sandström, P.; Skarin, A.; Stinnerbom, M.; Wik-Karlsson, J.; Sandström, S.; Österlin, C.; Buhot, Y. Kumulativa Effekter av Exploateringar på Renskötseln: Vad Behöver Göras Inom Tillståndsprocesser; Naturvårdsverket [Swedish Environmental Protection Agency] (SEPA), Rapport 6722. Available online: https:/ / www.naturvardsverket.se/Documents/publikationer6400/978-91-620-6722-9. pdf?pid=19076 (accessed on 30 May 2017).

49. Andersson, K. Geographic Information Systems as a Tool to Support Monitoring and Assessment of Landscape and Regional Sustainability. Ph.D. Thesis, Swedish University of Agricultural Sciences, Skinnskatteberg, Sweden, 2011.

50. Hållbar Utveckling i Översiktsplaneringen. Sustainable Development in the Municipal Comprehensive Planning. Available online: http://www.boverket.se/sv/PBL-kunskapsbanken/oversiktsplan/hallbarutveckling-i-oversiktsplaneringen/ (accessed on 1 June 2016).

51. Hyttinen, P.; Kola, J. Farm Forest and Rural Livelihood in Finland. J. Rural Stud. 1995, 11, 387-396. [CrossRef]

52. Westin, K.; Haugen, K.; Karlsson, S. New forest owners: Change and continuity in the characteristics of Swedish non-industrial private forest owners (NIPF owners). Small Scale For. 2016, 15, 1990-2010. [CrossRef]

53. Rennäringslagen [Reindeer Husbandry Act] 1979:437. Available online: http://www.notisum.se/rnp/sls / lag/19710437.HTM (accessed on 30 May 2017).

54. Kommunarealer den 1 Januari 2016. Available online: http://www.scb.se/MI0802/ (accessed on 19 May 2016).

55. Folkmängd i Riket, län och Kommuner 31 December 2014 och Befolkningsförändringar 2014. Available online: http:/ / www.scb.se/sv_/Hitta-statistik/Statistik-efter-amne/Befolkning/Befolkningenssammansattning/Befolkningsstatistik/25788/25795/Helarsstatistik---Kommun-lan-och-riket/385423/ (accessed on 19 May 2016).

56. Urbanisering-Från Land Till Stad. Available online: http://www.scb.se/sv_/Hitta-statistik/Artiklar/ Urbanisering-fran-land-till-stad/ (accessed on 22 September 2016).

57. Lundmark, L.; Marjavaara, R. Second home localizations in the Swedish mountain range. Tourism 2005, 53, 3-16.

58. Müller, D.K. Second home tourism in the Swedish mountain range. In Nature-Based Tourism in Peripheral Areas: Development or Disaster; Hall, C.M., Boyd Clevedon, S., Eds.; Channel View Publications: Buffalo, NY, USA, 2005; pp. 133-148.

59. Bergman, I.; Påsse, T.; Olofsson, A.; Zackrisson, O.; Hörnberg, G.; Hellberg, E.; Bohlin, E. Isostatic land uplift and Mesolithic landscapes: Lake-tilting, a key to the discovery of Mesolithic sites in the interior of Northern Sweden. J. Archaeol. Sci. 2003, 30, 1451-1458. [CrossRef]

60. Förhistoria. Available online: http://www.museum.vilhelmina.se/forhistoria.html (accessed on 17 January 2017).

61. Aronsson, K.Å. Forest Reindeer Herding AD 1-1800. An Archaeological and Palaeoecological Study in Northern Sweden; Archaeology and Environment 10; Department of Archaeology, Umeå University: Umeå, Sweden, 1991.

62. Hansen, L.I.; Olsen, B.; Larson, P. Samernas Historia Fram Till 1750; Liber: Stockholm, Sweden, 2006.

63. Sametinget 2014. The Sami Parliament 2014. Available online: http://www.sametinget.se/statistik/ (accessed on 29 November 2016).

64. Pettersson, O.P. Gamla Byar i Vilhelmina; I-II samt III-IV; Två Förläggare: Umeå, Sweden, 1982.

65. Östlund, L.; Zackrisson, O.; Axelsson, A.-L. The history and transformation of a Scandinavian boreal forest landscape since the 19th century. Can. J. For. Res. 1997, 27, 1198-1206. [CrossRef]

66. Svensson, J.; Sandström, P.; Sandström, C.; Jougda, L.; Baer, K. Sustainable landscape management in the Vilhelmina Model Forest, Sweden. For. Chron. 2012, 88, 291-297. [CrossRef] 
67. Sjölander, E.; Strömberg, M.; Degerman, E.; Göthe, L.; Jougda, L. Åtgärdsplanering i Reglerade Vattendrag-Arbetsgång och Åtgärdsförslag i övre Ångermanälven; Skogsstyrelsens rapport 2009:1; Skogsstyrelsens Förlag: Jönköping, Sweden, 2009. (In Swedish)

68. Wind Power Plan for South Lapland, Complement to Comprehensive Plan; Dorotea, Vilhemina and Åsele municipalities: Dorotea, Vilhemina and Åsele, Sweden, 2010. (In Swedish)

69. Vindbrukskollen. Available online: http://www.vindlov.se/sv/vindbrukskollen1/karta/ (accessed on 29 November 2016).

70. Anon. Vilhelmina Municipality, Comprehensive Plan; Vilhelmina Municipality: Vilhelmina, Sweden, 2000. (In Swedish)

71. Mineralrättigheter. Available online: https://apps.sgu.se/kartvisare/kartvisare-mineralrattigheter.html (accessed on 29 November 2016).

72. Heberlein, T.A.; Fredman, P.; Vuorio, T. Current tourism patterns in the Swedish mountain region. Mt. Res. Dev. 2002, 22, 142-149. [CrossRef]

73. Zachrisson, A.; Sandell, K.; Fredman, P.; Eckerberg, K. Tourism and protected areas: motives, actors and processes. Int. J. Biodivers. Sci. Manag. 2006, 2, 350-358. [CrossRef]

74. Zachrisson, A. Deliberative Democracy and Co-management of Natural Resources: Snowmobile Regulation in Western Sweden. Int. J. Common. 2009, 4, 273-292. [CrossRef]

75. Beland Lindahl, K.; Baker, S.; Rist, L.; Zachrisson, A. Theorising pathways to sustainability. Int. J. Sustain. Dev. World Ecol. 2015, 23, 399-411. [CrossRef]

76. Sandström, P. A Toolbox for Co-Production of Knowledge and Improved Land Use Dialogues-The Perspective of Reindeer Husbandry. Ph.D. Thesis, Umeå University, Umeå, Sweden, 2015.

77. Lillesand, T.M.; Kiefer, R.W.; Chipman, J.W. Remote Sensing and Image Interpretation; John Wiley: New York, NY, USA, 2008.

78. Svensson, J.; Sandström, P.; Andersson, J.; Mikusiński, G.; Jonsson, B.-G. Spatiotemporal coast to mountain green infrastructure trajectory of continuous cover forests in boreal northern Sweden. Forthcoming.

79. Reese, H.; Nilsson, M.; Pahlen, T.G.; Hagner, O.; Joyce, S.; Tingelöf, U.; Egberth, M.; Olsson, H. Countrywide estimates of forest variables using satellite data and field data from the national forest inventory. AMBIO 2003, 32, 542-548. [CrossRef] [PubMed]

80. Fridman, J.; Holm, S.; Nilsson, M.; Nilsson, P.; Ringvall, A.H.; Ståhl, G. Adapting National Forest Inventories to changing requirements-The case of the Swedish National Forest Inventory at the turn of the 20th century. Silv. Fenn. 2014, 48. [CrossRef]

81. Road Map; Land Cover. Digital Layer; Lantmäteriet [Swedish National Land Survey]: Gävle, Sweden, 2016.

82. Economic Map; Property Borders. Digital Layer; Lantmäteriet [Swedish National Land Survey]: Gävle, Sweden, 2016.

83. Registry of Forest Holdings and Forest Owners in Vilhelmina Municipality; Excel File; Skogsstyrelsen [Swedish Forest Agency] (SFA): Vilhelmina, Sweden, 2016.

84. Naturvårdsavtal. Nature Management Agreements. Available online: http://skogsdataportalen. skogsstyrelsen.se/Skogsdataportalen/ (accessed on 30 November 2016).

85. Biotopskydd. Biotope Protection. Available online: http://skogsdataportalen.skogsstyrelsen.se/ Skogsdataportalen/ (accessed on 30 November 2016).

86. Skog och Historia. Forest and History. Available online: http://skogsdataportalen.skogsstyrelsen.se/ Skogsdataportalen/ (accessed on 30 November 2016).

87. Databasen Fornsök. Available online: http://www.raa.se/hitta-information $/$ fornsok-fmis $/$ ?utm_source= startsida\&utm_medium=snabblank\&utm_campaign=ux-test (accessed on 29 November 2016).

88. Hörnsten, L.; Fredman, P. On the distance to recreational forests in Sweden. Landsc. Urban Plan. 2000, 51, 1-10. [CrossRef]

89. Economic Map; Residencies. Digital Layer; Lantmäteriet [Swedish National Land Survey]: Gävle, Sweden, 2016.

90. Jaktförordningen [Hunting Decree] 1987:905. Available online: https://www.riksdagen.se/sv/ dokument-lagar/dokument/svensk-forfattningssamling/jaktforordning-1987905_sfs-1987-905 (accessed on 30 May 2017).

91. Jordförvärvslag [Aqusition Law] 1979:230. Available online: https://www.riksdagen.se/sv/ dokument-lagar/dokument/svensk-forfattningssamling/jordforvarvslag-1979230_sfs-1979-230 (accessed on 30 May 2017). 
92. Förändrat Uppdrag för Sveaskog AB. Regeringens Proposition 2009/10:169. Available online: https:/ / data. riksdagen.se/fil/30822CF7-561D-4D73-A0E0-709EDC70A643 (accessed on 30 May 2017).

93. Nature Reserves. Available online: http://extra.lansstyrelsen.se/gis/Sv/Pages/nationella-geodata.aspx (accessed on 20 June 2016).

94. Sveaskog AB och Dess Uppdrag; Rapport RiR 2010:8. Available online: http://www.riksrevisionen.se/ PageFiles/1958/RiR_2010_8.pdf (accessed on 30 May 2017).

95. Lindgren, J. Sveaskogs Försäljning av Skogsmark i Vilhelmina och Dorotea-Målsättning och Utfall ur ett Glesbygdsperspektiv [Sale of Sveaskogs Forestland in Vilhelmina and Dorotea-Aims and Outcomes from a Rural Perspective]. Master's Thesis, Department of Forest Research, Swedish University of Agricultural Sciences, Umeå, Sweden, 2013.

96. Bergström, L.-E.; (Sveaskog, Älvsbyn, Sweden). Personal communication, 15 November 2016.

97. Lidestav, G.; Thellbro, C.; Sandström, P.; Lind, T.; Holm, E.; Olsson, O.; Westin, K.; Karppinen, H.; Ficko, A. Interactions between forest owners and their forests. In Globalisation and Change in Forest Ownership and Forest Use: Natural Resource Management in Transition; Keskitalo, E.C.H., Ed.; Palgrave Macmillan: Basingstoke, UK, in press.

98. Enander, K.-G. Skogsbrukssätt och Skogspolitik 1950-2000; Report No. 54; Swedish University of Agricultural Sciences, Department of Silviculture: Umeå, Sweden, 2003; ISSN 0348-8969.

99. Strategi för Formellt Skydd av Skog; County Administrative Board of Västerbotten: Umeå, Sweden, 2006.

100. Olsson, O. Changed availability of urban fringe forests in Sweden in 2000-2010. Scand. J. For. Res. 2013, 28, 386-394. [CrossRef]

101. Olsson, O. Out of the Wild: Studies on the Forest as a Recreational Resource for Urban Residents. Ph.D. Thesis, Umeå University, Umeå, Sweden, 2014.

102. Atlegrim, O.; Sjöberg, K. Comparison of invertebrate abundance and biomass between a clear-cut stand and four stands under tree cover in Swedish boreal coniferous forests. Entomol. Fenn. 1996, 7, 17-27.

103. Nilson, M. Large Scale Landscape Composition and Structure in Managed and Pristine European Taiga. Bachelor's Thesis, Swedish University of Agricultural Sciences, Department of Wildlife Ecology, Grimsö Wildlife Research Station, Riddarhyttan, Sweden, 1996.

104. Axelsson Lindgren, C. En Semantisk Modell för Skogsupplevelse; Arbetsrapport 99:3; Sveriges Lantbruksuniversitet, institutionen för landskapsplanering: Alnarp, Sweden, 1999.

105. Thellbro, C.; Lidestav, G. Local Natural Resource Dependency in Rural Boreal Sweden. Faculty of Forestry, Swedish University of Agricultural Sciences, Umeå. Studia Forestalia Suecica 2008, 14. ISSN 0039-3150; 215. ISBN 978-91-85911-41-7. Available online: http:/ / www-umea.slu.se/bibum/studia/index.cfm?volid=215 (accessed on 10 January 2017).

106. Hooper, R. Learning about Vilhelmina Kommun-Climate, Impacts and Adaptation. A Vilhelmina Model Forest Project; Report; Swedish University of Agricultural Sciences and University of British Columbia: Umeå, Sweden; Vancouver, BC, Canada, 2012.

107. Löf, A.; Sandström, P.; Baer, K.; Stinnerbom, M.; Sandström, C. Renskötsel och klimatförändring-Risker, sårbarhet och anpassnings-möjligheter i Vilhelmina norra sameby. In Statsvetenskapliga Institutionens Skriftserie; Forskningsrapport 2012:4; Umeå Universitet, Statsvetenskapliga institutionen: Umeå, Sweden, 2012.

108. Sandström, P.; Sandström, C.; Svensson, J.; Jougda, L.; Baer, K. Participatory GIS to mitigate conflicts between reindeer husbandry and forestry in Vilhelmina Model Forest, Sweden. For. Chron. 2012, 88, 254-260. [CrossRef]

109. Nilsson, H. Strategic Forest Planning Using AHP and TOPSIS in Participatory Environments-A Case Study Conducted in Vilhelmina, Sweden. Master's Thesis, Department of Forest Resource Management, Swedish University of Agricultural Sciences, Umeå, Sweden, 2014.

110. Olofsson, I. Nyckelbiotoper och Kontinuitetsskog i Vilhelmina Kommun-I ett Landskapsperspektiv. Woodland Key Habitats and Continuous Cover Forests in Vilhelmina Municipality-A Landscape Approach; Kandidatarbete. Institutionen för Skogens Ekologi och Skötsel, Sveriges Lantbruksuniversitet: Umeå, Sweden, 2014. (With English Summary)

111. Carlsson, J. Participatory Scenario Analysis in Forest Resource Management. Exploring Methods and Governance Challenges from a Rural Landscape Perspective. Ph.D. Thesis, Department of Forest Resource Management, Swedish University of Agricultural Sciences, Umeå, Sweden, 2017. 
112. Berge, B.; Adolfson, B. Effektiva Planeringsprocesser i-Strategier för Ytstora Kommuner med Liten Befolkning; Slutrapport; Länsstyrelserna i Norrbotten och Västerbotten: Umeå and Luleå, Sweden, 2011.

113. Aktuella Kommunomfattande Översiktsplaner. Läget i Landet Mars 2014. [Current Municipal Comprehensive Plans. The Situation in the Country in March 2014]; Report; Sveriges Kommuner och Landsting [Association of Local Authorities and Regions] (SKL): Stockholm, Sweden, 2014; p. 18. (In Swedish)

114. Syssner, J.; Olausson, A. Översiktsplanering I kommuner som krymper [Comprehensive Planning in Shrinking Municipalities]. Statsvetensk. Tidskr. 2016, 2016, 118.

115. Stjernström, O.; Ahas, R.; Bergstén, S.; Eggers, J.; Hain, H.; Karlsson, S.; Keskitalo, E.C.H.; Lämås, T.; Pettersson, Ö.; Sandström, P.; et al. Multilevel planning and conflicting interests in the forest landscape. In Globalisation and Change in Forest Ownership and Forest Use. Natural Resource Management in Transition; Keskitalo, E.C.H., Ed.; Palgrave Macmillan: Basingstoke, UK, in press.

(c) 2017 by the authors. Licensee MDPI, Basel, Switzerland. This article is an open access article distributed under the terms and conditions of the Creative Commons Attribution (CC BY) license (http:/ / creativecommons.org/licenses/by/4.0/). 